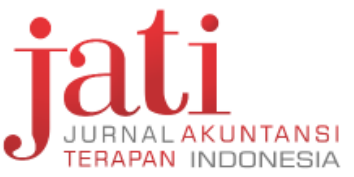

Jati: Jurnal Akuntansi Terapan Indonesia Vol 1 No 2 Hal 82-90 Oktober 2018

\title{
Analisis Penilaian Aset Tetap PT. Garuda Indonesia (Persero) Tbk dalam Meminimalkan Beban Pajak Penghasilan dan Upaya Mengontrol Permodalan
}

\author{
http://journal.umy.ac.id/index.php/jati \\ (C) $2018 \mathrm{JATI}$. All rights reserved \\ DOI: 10.18196/jati.010209
}

\section{DATA ARTIKEL:}

Diterima: 16 September 2018

Direviu: 18 September 2018

Direvisi: 29 Oktober 2018

Disetujui: 30 Oktober 2018

\section{TOPIK ARTIKEL:}

Analisis Laporan Keuangan

ABSTRAK: Penelitian ini bertujuan untuk mengetahui dan memahami seberapa besar pengaruh revaluasi aset tetap untuk upaya meminimalkan beban pajak penghasilan dan upaya mengontrol permodalan. Penelitian ini dilaksanakan pada PT Garuda Indonesia (Persero) Tbk yang diteliti menggunakan Metode Deskriptif dengan pendekatan Kualitatif. Objek dari penelitian ini yaitu laporan laba rugi dan penghasilan komprehensif periode 2016 dan 2017, laporan posisi keuangan konsolidasian periode 2016 dan 2017, daftar penyusutan aset tetap sebelum dan sesudah revaluasi yang diperoleh dari website resmi perusahaan. Tindakan revaluasi aset tetap yang dilakukan oleh pihak perusahaan dikatakan belum mampu menghemat beban pajak penghasilan karena beban pajak yang harus disetor perusahaan sebelum revaluasi aset tetap sebesar USD 8.425.842, sedangkan setelah melakukan revaluasi aset tetap sebesar USD 55.209.041. Beban bunga pinjaman yang dikeluarkan perusahaan boleh seutuhnya diakui sebagai beban dan tidak perlu dikoreksi fiskal karena telah sesuai dengan peraturan, tidak melebihi batas maksimal.

Kata Kunci: Penilaian Kembali Aset tetap, Beban Pajak Penghasilan, Beban Bunga Pinjaman

ABSTRACT: The research aimed to learning and understanding how big the effect of fixed asset revaluation in minimizing income tax expense and the efforts to control the capital is. This research in PT Garuda Indonesia (Persero) Tbk. The method that used was descriptive with a qualitative approach. The objects of the re-search were the income statement and the comprehensive income from 2016 - 2017, the consolidated statement of financial position of 2016 and 2017, prior and post-revaluation list of decreasing assets collected from the official website of the company. The fixed assets revaluation conducted by the company was not yet able to save income tax expense since the tax expense which had to be paid before the fixed asset revaluation was US\$ 8.425 .842 and US\$ 55.209 .041 after revaluation. The income tax expense paid by the company may be considered as an expense which needed no fiscal correction since it accorded with the regulations, did not exceed the maximum.

Keywords: Fixed asset revaluation, Income tax expense, loan interest expense

\section{SITASI ARTIKEL:}

Gunawan, B., \& Hapsari, G., Y. (2018). Analisis Penilaian Aset Tetap PT Garuda Indonesia (Persero) Tbk dalam meminimalkan Beban Pajak Penghasilan dan Upaya Mengontrol Permodalan. Jati: Jurnal Akuntansi Terapan Indonesia, 1(2), 82-90.

\section{PENDAHULUAN}

Beban pajak penghasilan yang harus dibayar lebih oleh agen pembangunan nasional membuat beberapa BUMN berupaya dalam perihal penghematan beban pajak demi mencapai tujuan perusahaan yaitu mencapai laba yang maksimal. Sehingga, ada beberapa BUMN yang menghalalkan segala cara demi menghemat pajak penghasilan. Oleh karena itu, sebaiknya perusahaan sebelum berupaya menghemat beban pajak lebih baik untuk memantapkan perencanaan pajak terlebih dahulu. Perencanaan pajak dapat dilakukan dengan berbagai cara seperti penentuan transfer pri- 
cing, manajemen persediaan, pemberian tunjangan, penilaian kembali aset tetap (revaluasi aset tetap), dll.

PT Garuda Indonesia (Persero) Tbk merupakan maskapai penerbangan yang dimiliki oleh Pemerintah Republik Indonesia yang menyediakan pesawat komersial untuk penumpang, kargo, dan jasa lainnya yang berkaitan dengan transportasi udara. Dapat disimpulkan bahwa PT Garuda Indonesia (Persero) Tbk memiliki deretan aset tetap dengan jumlah yang banyak dan besar. Dapat juga dipastikan aset tetap yang dimiliki PT Garuda Indonesia (Persero) Tbk harus melewati tahap revaluasi seperti rangka pesawat, mesin, kendaraan, bangunan, dll.

Revaluasi Aset adalah penilaian kembali aset tetap perusahaan, yang diakibatkan adanya kenaikan nilai aset tetap tersebut di pasaran atau karena rendahnya nilai aset tetap dalam laporan keuangan perusahaan yang disebabkan oleh devaluasi atau sebab lain, sehingga nilai aset tetap dalam laporan keuangan tidak lagi mencerminkan nilai yang wajar. Revaluasi aset memiliki banyak keuntungan bagi perusahaan yang melakukan kebijakan tersebut. Keuntungan dari melakukan revaluasi aset tetap yaitu Pertama, mampu meminimalkan beban pajak penghasilan yang sebagaimana telah difasilitasi oleh pemerintah, yaitu pemotongan PPh Final atas selisih nilai aset tetap dan telah tertuang dalam Peraturan Menteri Keuangan Nomor 191/PMK.03/2015 penilaian kembali aset tetap perusahaan untuk tujuan perpajakan bagi permohonan yang diajukan pada tahun 2015 dan tahun 2016. Hal ini dibuktikan oleh Atikasari \& Handayani (2017) yang menemukan bahwa revaluasi asset tetap mampu meningkatkan nilai buku asset tetap PT Damai Sejahtera Abadi. Kedua, perusahaan mampu mengontrol permodalan untuk mencapai struktur modal yang sehat maka perusahaan harus mempertahankan rasio modal yang optimal dan peringkat kredit yang kuat. Selama pinjaman yang digunakan oleh perusahaan akan muncul biaya pinjaman dan biaya pinjaman tersebut diperhitungkan dalam menghitung Penghasilan Kena Pajak. Pembebasan koreksi fiskal pada biaya pinjaman dilakukan pada saat rasio modal terhadap hutang tidak melampaui batas maksimal yang telah tertuang di Peraturan Menteri Keuangan Nomor 169/PMK.010/2015.

Berdasarkan uraian tersebut, penelitian ini berupaya untuk melakukan penelitian mengenai apakah dengan melakukan revaluasi aset tetap mampu menggerakkan penghematan beban pajak pada sebuah perusahaan dan mampu mengontrol permodalan perusahaan. Revaluasi aset tetap dipilih oleh peneliti untuk diteliti karena peneliti menilai bahwa revaluasi aset tetap bukan merupakan akti- vitas rutin suatu perusahaan dalam upaya meminimalkan beban pajak perusahaan dan upaya mengontrol permodalan. Aset tetap merupakan salah satu aset perusahaan yang memiliki nilai cukup besar dan sangat penting bagi perusahaan.

Penelitian ini merupakan replikasi dari penelitian Ramadhan (2013) di PT INKA Madiun. Penelitian yang akan dilakukan tidaklah sama dengan replikasi yang dijadikan acuan sehingga jika dibandingkan dengan replikasi yang telah disebutkan perbedaannya terletak pada periode laporan keuangan yang digunakan, pelaksanaan revaluasi dan perusahaan yang akan diteliti. Oleh karena itu, penelitian ini melakukan analisis penilaian aset tetap pada PT Garuda Indonesia (Persero) Tbk dalam meminimalkan beban pajak penghasilan dan upaya mengontrol permodalan.

\section{METODE PENELITIAN}

Peneliti memilih PT Garuda Indonesia (Persero) Tbk dengan Data laporan laba rugi dan penghasilan komprehensif untuk tahun berakhir 31 Maret 2018 serta daftar penyusutan aset tetap sebelum dan sesudah revaluasi sebagai objek penelitiannya. Objek data yang akan digunakan merupakan jenis data sekunder yang di peroleh dari website resmi PT Garuda Indonesia (Persero) Tbk. Yang mana data tersebut diperoleh dengan studi kepustakaan yang akan diteliti dengan metode deskriptif dengan pendekatan kualitatif. Yang mana sebelum peneliti menyelesaikan tugas ini sebelumnya peneliti harus mengumpulkan data laporan laba rugi dan penghasilan komprehensif periode 2016 dan 2017, laporan posisi keuangan konsolidasian periode 2016 dan 2017, daftar penyusutan aset tetap sebelum dan sesudah revaluasi, metode penyusutan aset tetap, dan harga perolehan aset tetap. Dalam penelitian ini, aset yang direvaluasi terdiri dari aset pesawat dan aset non pesawat.

Kemudian, langkah yang ditempuh peneliti dalam menyelesaikan penelitian ini Pertama, peneliti membandingkan besarnya nilai buku aset dan beban penyusutan sebelum maupun setelah melakukan revaluasi aset. Yang dilanjutkan dengan menghitung besarnya pajak yang dapat dihemat akibat dilakukannya kebijakan revaluasi dengan tahap menentukan besarnya surplus revaluasi terlebih dahulu dengan cara mengurangkan selisih lebih revaluasi aset tetap dengan pajak tangguhan yang kemudian diikuti dengan menentukan besarnya pajak final sesuai dengan tarif yang digunakan. Setelah itu, peneliti juga membandingkan besarnya pajak terutang yang harus dibayar apabila melakukan revaluasi dan tidak melakukan revaluasi. Menanggapi keuntungan kedua dari revaluasi aset tetap menge- 
nai upaya mengontrol permodalan maka peneliti harus terlebih dahulu menghitung besarnya rasio hutang terhadap ekuitas yang kemudian di bandingkan untuk menilai posisi keuangan suatu perusahaan sehat atau tidak. Langkah yang terakhir yaitu menganalisis laporan keuangan dengan teknik analisis laporan keuangan komparatif berupa analisis perubahan tahun ke tahun (Year To Year Change Analysis).

\section{HASIL DAN PEMBAHASAN}

\section{Hasil Penelitian}

PT Garuda Indonesia (Persero) Tbk melakukan revaluasi aset tetap efektif dalam setahun sebanyak empat periode. Metode revaluasi yang digunakan perusahaan adalah revaluasi parsial. Revaluasi parsial merupakan metode revaluasi aset tetap yang hanya dilakukan pada sebagian aset perusahaan.

Penerapan kebijakan revaluasi aset tetap akan berpengaruh pada perubahan nilai aset dan dengan adanya perubahan pada nilai aset juga akan berdampak pada nilai beban penyusutan. Sehingga berdasarkan kondisi tersebut, maka laba fiskal PT Garuda Indonesia (Persero) Tbk secara otomatis juga akan mengalami perubahan dan atas peru-bahan laba fiskal perusahaan tersebut juga akan berpengaruh pada beban pajak penghasilan yang harus disetorkan karena beban pajak penghasilan dihitung berdasarkan laba fiskal yang diperoleh perusahaan. Apabila laba fiskal menjadi lebih kecil karena bertambahnya nilai penyusutan, maka besarnya beban pajak yang disetorkan juga akan menjadi kecil. Daftar penyusutan aset tetap perusahaan pada saat sebelum diterapkannya kebijakan revaluasi aset tetap dan setelah revaluasi dapat dilihat pada Tabel 1 dan Tabel 2 menunjukan adanya perbedaan nilai penyusutan dari aset tetap, yang mana beban penyusutan yang dikeluarkan perusahaan sebelum diterapkannya revaluasi aset tetap sebesar USD 4.312.501 sedangkan pada saat setelah diterapkan revaluasi aset tetap perusahaan mengeluarkan beban penyusutan sebesar USD 6.445.218. Jadi, beban penyusutan setelah revaluasi aset tetap lebih besar dibandingkan pada saat sebelum mela-kukan revaluasi aset tetap. Perubahan pada beban penyusutan tersebut mampu memberikan dampak pada laba yang diperoleh perusahaan.

Sehubungan dengan Laporan Laba Rugi dan Penghasilan Komprehensif Lain Konsolidasian yang telah disajikan dalam Tabel 3 dan Tabel 4 dapat diketahui bahwa beban pajak bersih yang harus dibayar perusahaan ketika tidak melakukan revaluasi aset tetap sebesar USD 8.425.842. Sedangkan, beban pajak yang dibayarkan perusahaan setelah melakukan revaluasi aset tetap sebesar USD 55.209.041 yang diperoleh dari hasil penjumlahan antara pajak tangguhan sebesar USD 36.325 .487 dengan pajak kini sebesar USD 18.883.554.

Untuk mengetahui dampak laba akibat dilakukannya revaluasi aset tetap oleh PT Garuda Indonesia (Persero) Tbk, maka dapat diketahui dengan membandingkan nilai buku aset tetap dengan nilai beban penyusutan baik setelah dilakukannya revaluasi aset tetap maupun sebelum. Tabel 5 merupakan hasil perbandingan nilai buku aset tetap dan nilai beban penyusutan sebelum revaluasi aset tetap dan setelah revaluasi aset tetap. Tabel 5 dapat terlihat adanya selisih lebih atas revaluasi aset tetap sebesar USD 100.275.545 (USD 453.294.124 - USD 353.018.579). Dengan kondisi tersebut aset perusahaan mengalami kenaikan nilai buku yang relatif besar. Pada Tabel 5 juga dapat dilihat bahwa aset pesawat berupa rangka pesawat mengalami peningkatan dari USD 43.830 .685 menjadi USD 60.236.988 dan aset pesawat berupa mesin mengalami peningkatan dari USD 65.585.139 menjadi USD 92.156.533. Sedangkan, aset non pesawat berupa tanah mengalami peningkatan dari USD 131.338.951 menjadi USD 166.109.948, dan untuk aset non pesawat berupa bangunan dan prasarana juga mengalami peningkatan dari USD 112.263.804 menjadi USD 134.790.655.

Tabel 1. Daftar Penyusutan Aset Tetap Periode yang Berakhir 31 Desember 2016 (Sebelum Revaluasi)

\begin{tabular}{lcrc}
\hline Nama Aset & $\begin{array}{c}\text { Nilai Pasar } \\
\text { USD }\end{array}$ & $\begin{array}{c}\text { Beban } \\
\text { Penyusutan } \\
\text { USD }\end{array}$ & \multicolumn{1}{c}{ Nilai Buku } \\
\hline ASET PESAWAT & & & \\
Rangka Pesawat & 45.315 .686 & 1.485 .001 & 43.830 .685 \\
Mesin & 67.616 .719 & 2.031 .580 & 65.585 .139 \\
ASET NON PESAWAT & & & \\
Tanah & 131.338 .951 & 0 & 131.338 .951 \\
Bangunan dan Prasarana & 113.059 .724 & 795.920 & 112.263 .804 \\
\hline TOTAL & 357.331 .080 & $\mathbf{4 . 3 1 2 . 5 0 1}$ & 353.018 .579 \\
\hline
\end{tabular}

Sumber: PT Garuda Indonesia (Persero) Tbk (2016). 
Tabel 2. Daftar Penyusutan Aset Tetap Periode yang Berakhir 31 Desember 2017 (Setelah Revaluasi)

\begin{tabular}{lcrc}
\hline Nama Aset & $\begin{array}{c}\text { Harga Perolehan } \\
\text { USD }\end{array}$ & $\begin{array}{c}\text { Beban } \\
\text { Penyusutan } \\
\text { USD }\end{array}$ & \multicolumn{1}{c}{ Nilai Buku } \\
\hline ASET PESAWAT & & & \\
Rangka Pesawat & 61.941 .852 & 1.704 .864 & 60.236 .988 \\
Mesin & 94.551 .629 & 2.395 .096 & 92.156 .533 \\
ASET NON PESAWAT & & & \\
Tanah & 166.109 .948 & 0 & 166.109 .948 \\
Bangunan dan Prasarana & 137.135 .913 & 2.345 .258 & 134.790 .655 \\
\hline TOTAL & 459.739 .342 & 6.445 .218 & 453.294 .124 \\
\hline
\end{tabular}

Sumber: PT Garuda Indonesia (Persero) Tbk (2017).

Tabel 3. Laporan Laba Rugi dan Penghasilan Komprehensif Lain Konsolidasian Untuk Periode yang Berakhir 31 Desember 2016 (Sebelum Revaluasi)

\begin{tabular}{ll}
\hline PT GARUDA INDONESIA (PERSERO) & PT GARUDA INDONESIA (PERSERO) TBK \\
TBK dan Entitas Anak & and Its Subsidiaries Consolidated Statements Of \\
Laporan Laba Rugi dan Penghasilan & Profit Or Loss and Other Comprehensive Income \\
Komprehensif Lain Konsolidasian Untuk & For The Periods Ended Dec 31, 2016.
\end{tabular}

Periode Yang Berakhir 31 Desember 2016.

\begin{tabular}{|c|c|c|}
\hline & $\begin{array}{l}2016 \\
\text { USD }\end{array}$ & \\
\hline PENDAPATAN USAHA & 3.863 .921 .565 & OPERATING REVENUES \\
\hline BEBAN USAHA & & OPERATING EXPENSES \\
\hline Operasional penerbangan & 2.187 .316 .263 & Flight operations \\
\hline Pemeliharaan dan perbaikan & 393.308 .458 & Maintenance and Overhaul \\
\hline Bandara & 334.047 .207 & User charges and station \\
\hline Tiket, penjualan dan promosi & 310.187 .732 & Ticketing, sales, and promotion \\
\hline Pelayanan penumpang & 286.289 .766 & Passenger services \\
\hline Administrasi dan umum & 226.797 .925 & General and administrative \\
\hline Operasional hotel & 28.180 .038 & Hotel operation \\
\hline Operasional transportasi & 17.848 .699 & Transportation operations \\
\hline Operasional jaringan & 11.951 .555 & Network operations \\
\hline Jumlah beban usaha & 3.795 .927 .643 & Total operating expenses \\
\hline BEBAN USAHA LAINNYA & & Other operating (income) charges \\
\hline Kerugian (keuntungan) selisih kurs & 19.170 .712 & Loss (gain) on foreign exchange \\
\hline Lain-Lain & $(50.280 .729)$ & Others \\
\hline Bersih & $(31.110 .017)$ & Net \\
\hline LABA (RUGI) USAHA & 99.103 .939 & Profit (loss) from operations \\
\hline Bagian laba (rugi) bersih asosiasi & $(215.172)$ & Equity in net gain (los) of associates \\
\hline Pendapatan keuangan & 7.180 .597 & Finance incomes \\
\hline Beban keuangan & $(88.278 .664)$ & Finance cost \\
\hline LABA (RUGI) SEBELUM PAJAK & 17.790 .700 & Profit (loss) before tax \\
\hline Pajak Kini & $(17.960 .427)$ & Current tax \\
\hline Pajak tangguhan & 9.700 .306 & Deferred tax \\
\hline BEBAN PAJAK & $(8.425 .842)$ & Tax expenses \\
\hline LABA (RUGI) BERSIH & 9.364 .858 & Net profit (loss) for the current year \\
\hline
\end{tabular}

Sumber: PT Garuda Indonesia (Persero) Tbk (2016). 
Tabel 4. Laporan Laba Rugi dan Penghasilan Komprehensif Lain Konsolidasian Untuk Periode Yang Berakhir 31 Desember 2017 (Setelah Revaluasi)

$\begin{array}{ll}\text { PT GARUDA INDONESIA (PERSERO) } & \text { PT GARUDA INDONESIA (PERSERO) TBK } \\ \text { TBK dan Entitas Anak } & \text { and Its Subsidiaries Consolidated Statements Of } \\ \text { Laporan Laba Rugi dan Penghasilan } & \text { Profit Or Loss and Other Comprehensive Income } \\ \text { Komprehensif Lain Konsolidasian Yang } & \text { Ended Dec 31, 2017. }\end{array}$

Berakhir 31 Desember 2017.

\begin{tabular}{|c|c|c|}
\hline & $\begin{array}{l}2017 \\
\text { USD }\end{array}$ & \\
\hline PENDAPATAN USAHA & 4.177 .325 .781 & OPERATING REVENUES \\
\hline BEBAN USAHA & & OPERATING EXPENSES \\
\hline Operasional penerbangan & 2.478 .025 .975 & Flight operations \\
\hline Pemeliharaan dan perbaikan & 429.361 .211 & Maintenance and Overhaul \\
\hline Bandara & 382.651 .073 & User charges and station \\
\hline Tiket, penjualan dan promosi & 323.723 .174 & Ticketing, sales, and promotion \\
\hline Pelayanan penumpang & 298.973 .443 & Passenger services \\
\hline Administrasi dan umum & 265.808 .770 & General and administrative \\
\hline Operasional hotel & 26.125 .254 & Hotel operation \\
\hline Operasional transportasi & 21.028 .192 & Transportation operations \\
\hline Operasional jaringan & 12.076 .240 & Network operations \\
\hline Jumlah beban usaha & 4.237 .773 .332 & Total operating expenses \\
\hline BEBAN USAHA LAINNYA & & Other operating (income) charges \\
\hline Beban pengampunan pajak & 50.307 .992 & Tax amnesty expenses \\
\hline Kerugian (keuntungan) selisih kurs & $(14.777 .069)$ & Loss (gain) on foreign exchange \\
\hline Lain-Lain & $(19.797 .296)$ & Others \\
\hline Bersih & 15.733 .627 & Net \\
\hline LABA (RUGI) USAHA & $(76.181 .178)$ & Profit (loss) from operations \\
\hline Bagian laba (rugi) bersih asosiasi & 192.617 & Equity in net gain (los) of associates \\
\hline Pendapatan keuangan & 6.196 .164 & Finance incomes \\
\hline Beban keuangan & $(88.388 .240)$ & Finance cost \\
\hline LABA (RUGI) SEBELUM PAJAK & $(158.180 .637)$ & Profit (loss) before tax \\
\hline Pajak Kini & $(18.883 .554)$ & Current tax \\
\hline Pajak tangguhan & $(36.325 .487)$ & Deferred tax \\
\hline BEBAN PAJAK & $(55.209 .041)$ & Tax expenses \\
\hline LABA (RUGI) BERSIH & $(213.389 .678)$ & Net profit (loss) for the current year \\
\hline
\end{tabular}

Sumber: PT Garuda Indonesia (Persero) Tbk (2017).

Tabel 5. Perbandingan Nilai Buku Aset Tetap Dan Beban Penyusutan

\begin{tabular}{|c|c|c|c|c|}
\hline \multirow[b]{2}{*}{ Nama Aset } & \multicolumn{2}{|c|}{ Sebelum Revaluasi } & \multicolumn{2}{|c|}{ Sesudah Revaluasi } \\
\hline & $\begin{array}{c}\text { Nilai Buku } \\
\text { USD }\end{array}$ & $\begin{array}{c}\text { Beban } \\
\text { Penyusutan } \\
\text { USD }\end{array}$ & $\begin{array}{c}\text { Nilai Buku } \\
\text { USD }\end{array}$ & $\begin{array}{c}\text { Beban } \\
\text { penyusutan } \\
\text { USD }\end{array}$ \\
\hline \multicolumn{5}{|c|}{ ASET PESAWAT } \\
\hline Rangka Pesawat & 43.830 .685 & 1.485 .001 & 60.236 .988 & 1.704 .864 \\
\hline Mesin & 65.585 .139 & 2.031 .580 & 92.156 .533 & 2.395 .096 \\
\hline \multicolumn{5}{|c|}{ ASET NON PESAWAT } \\
\hline Tanah & 131.338 .951 & - & 166.109 .948 & - \\
\hline $\begin{array}{l}\text { Bangunan dan } \\
\text { Prasarana }\end{array}$ & 112.263 .804 & 795.920 & 134.790 .655 & 2.345 .258 \\
\hline TOTAL & 353.018 .579 & 4.312 .501 & 453.294 .124 & 6.445 .218 \\
\hline
\end{tabular}

Sumber: PT Garuda Indonesia (Persero) Tbk (2016 dan 2017). 


\section{Pembahasan}

Kewajiban pajak PT Garuda Indonesia (Persero) Tbk tidak sekedar sebesar USD 55.209.041 yang disetorkan ke kas negara, tetapi terdapat pajak final yang juga menjadi kewajiban perusahaan akibat adanya selisih lebih akibat revaluasi aset tetap. Sedangkan, Pada tanggal 22 Desember 2015, Perusahaan mengajukan "Permohonan penilaian kembali aktiva tetap untuk tujuan perpajakan pada tahun 2015 oleh wajib pajak yang belum melakukan penilaian kembali aktiva tetap" kepada Kepala Kantor Wilayah Wajib Pajak Besar melalui surat No. GARUDA/JKTDF/ 20459/15. Oleh karena itu, PT Garuda Indonesia (Persero) Tbk menggunakan tarif Pajak Penghasilan yang bersifat final sebesar 3\% sesuai dengan Peraturan Menteri Keuangan (PMK) Nomor 191/PMK.010/2015 tanggal 15 Oktober 2015 yang telah diubah dengan PMK Nomor 233/PMK.03/2015 tanggal 21 Desember 2015 dan harus dikonversi terlebih dahulu ke satuan mata uang Rupiah (Rp) yang beredar pada saat pembayaran dikarenakan pada saat melakukan revaluasi aset perusahaan menggunakan satuan mata uang Dollar Amerika Serikat (USD). Sehingga, dapat diketahui pajak final yang harus disetor oleh perusahaan sebagai berikut:

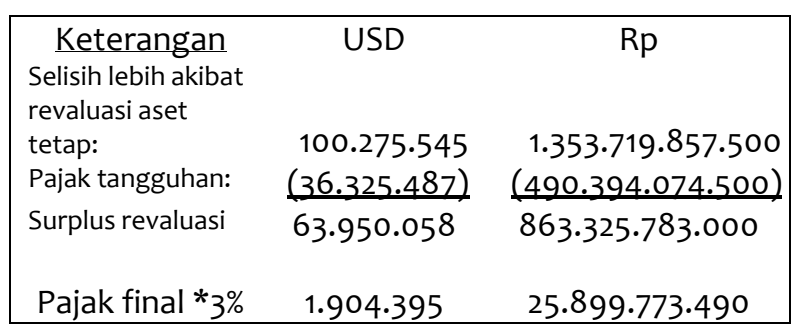

Pajak final yang muncul akibat revaluasi aset tetap sebesar Rp 25.899.773.490. Tahap selanjutnya untuk menganalisis lebih lanjut apakah revaluasi aset tetap yang dilakukan oleh perusahaan mampu meminimalkan beban pajak penghasilan atau tidak maka perlu adanya perbandingan besarnya pajak penghasilan yang harus disetor sebelum revaluasi aset tetap maupun setelah revaluasi. Tabel 6 merupakan tabel hasil analisis mengenai perbandingan besarnya pajak penghasilan yang harus disetor sebelum revaluasi aset tetap maupun setelah revaluasi.

Adanya pengenaan pajak final tersebut menyebabkan timbulnya perbedaan besarnya pajak terutang yang disetorkan sebelum maupun sesudah revaluasi aset tetap. Kebijakan revaluasi aset tetap yang dilakukan oleh perusahaan pada periode 2017 dapat dikatakan belum berhasil dalam upaya penghematan beban pajak penghasilan. Hal tersebut dikarenakan meningkatnya beban pajak yang harus disetor oleh perusahaan, yang mana saat sebelum melakukan revaluasi aset tetap beban pajak yang harus dibayarkan sebesar USD 8.425.842, sedangkan setelah melakukan revaluasi aset sebesar USD 57.113.436. Karena PT Garuda Indonesia (Persero) Tbk hanya melakukan pada beberapa aset tetap saja atau sering disebut dengan revaluasi parsial.

Dampak yang timbul akibat adanya kebijakan revaluasi aset tetap yaitu perubahan pada laba atau rugi yang dihasilkan perusahaan yang selanjutnya juga akan berpengaruh pada beban pajak terutang yang harus dibayarkan. Revaluasi aset tetap juga mampu memberikan perubahan pada nilai buku suatu aset dan diikuti oleh nilai beban penyusutannya. Ada satu aset yang yang tidak dapat disusutkan yaitu tanah sehingga melakukan revaluasi aset tetap pada tanah ini tidak memberikan kontribusi dalam upaya penghematan pajak karena tidak menghasilkan beban penyusutan. Sedangkan untuk aset rangka pesawat, mesin, bangunan dan prasarana mampu memberikan kontribusi dalam upaya penghematan beban pajak melalui peningkatan beban penyusutan. Meskipun, pada akhirnya kebijakan revaluasi aset tetap ini tidak mampu menghemat pajak penghasilan secara maksimal.

Menanggapi keuntungan yang di dapat dari revaluasi aset tetap selain menghemat beban pajak penghasilan yaitu perusahaan mampu mengontrol permodalan untuk memperlihatkan posisi kekayaan yang wajar agar lebih akurat. Sehingga untuk mencapai struktur modal yang sehat maka perusahaan harus mempertahankan rasio modal yang optimal dan peringkat kredit yang kuat. Selama pinjaman yang digunakan oleh perusahaan akan muncul biaya pinjaman dan biaya pinjaman tersebut diperhitungkan dalam menghitung PKP. Pembebasan koreksi fiskal pada biaya pinjaman dilakukan pada saat rasio modal terhadap hutang tidak melampaui batas maksimal yang telah tertuang di Peraturan Menteri Keuangan Nomor 169/PMK.010/2015 tentang penentuan besarnya perbandingan antara hutang dan modal perusahaan untuk keperluan perhitungan PPh sehingga dapat mengetahui Rasio Utang terhadap Ekuitas atau Debt to Equity Ratio (DER) yang dialami perusahaan. Ketentuan besarnya perbandingan hutang dan modal sebesar empat berbanding satu (4:1). Dengan demikian perusahaan melakukan revaluasi aset tetap agar biaya pinjaman yang telah diperhitungkan dalam menghitung Penghasilan Kena Pajak tidak dikoreksi fiskal karena jika DER melampaui DER maksimal maka biaya pinjaman yang tidak boleh dibebankan sebesar selisih DER dikali biaya pinjaman. Tabel 7 menunjukkan perbandingan Debt to Equity Ratio (DER). 
Tabel 6. Perbandingan Besarnya Pajak Penghasilan

\begin{tabular}{lrr}
\hline \multicolumn{1}{c}{ Jenis Pajak } & Sebelum Revaluasi & \multicolumn{2}{c}{ Setelah Revaluasi } \\
& USD & \multicolumn{1}{c}{ USD } \\
\hline Beban Pajak & 8.425 .842 & 55.209 .041 \\
Pajak Final atas Selisih revaluasi aset tetap & - & 1.904 .395 \\
\hline TOTAL & $\mathbf{8 . 4 2 5 . 8 4 2}$ & $\mathbf{5 7 . 1 1 3 . 4 3 6}$ \\
\hline
\end{tabular}

Sumber: Data diolah (2018)

Tabel 7. Perbandingan Debt to Equity Ratio (DER)

\begin{tabular}{lrr}
\hline \multirow{2}{*}{ Nama Akun } & Sebelum Revaluasi & Setelah Revaluasi \\
& USD & \multicolumn{1}{c}{ USD } \\
\hline Hutang & 1.694 .066 .936 & 1.715 .459 .053 \\
Ekuitas & 1.009 .897 .219 & 937.469 .200 \\
\hline Debt to Equity Ratio (DER) & $\mathbf{1 , 7}$ & $\mathbf{1 , 8}$ \\
\hline
\end{tabular}

Sumber: Data diolah (2018)

Berdasarkan Tabel 7 dapat diketahui bahwa tidak ada koreksi fiskal dikarenakan telah sesuai dengan Peraturan Menteri Keuangan Nomor 169 /PMK.010/2015 yang membatasi perbandingan hutang dengan ekuitas maksimal sebesar empat berbanding satu (4:1). Sedangkan perbandingan hutang dan ekuitas pada saat sebelum revaluasi aset tetap 1,7:1 dan 1,8:1 setelah revaluasi aset tetap dilakukan. Sehingga beban bunga pinjaman yang dibayarkan oleh perusahaan tidak perlu dikoreksi fiskal.

Untuk membantu para investor dan para pengguna lainnya, peneliti melakukan analisis laporan keuangan komparatif dengan teknik analisis perubahan dari tahun ke tahun (Year to year change analysis) yang telah dipaparkan dalam Tabel 8. Analisis tersebut menunjukkan beberapa pos dalam catatan atas laporan keuangan. Pertama, apabila dilihat dari akun pendapatan usaha mengalami kenaikan sebesar $8,11 \%$. Pendapatan usaha yang diperoleh perusahaan tersebut diikuti dengan adanya beberapa pengeluaran yang mengalami naik dan turun juga. Yang pertama, ada beban operasional penerbangan yang mengalami kenaikan sebesar $13,29 \%$. Pemeliharaan dan perbaikan merupakan beban yang berasal dari pemeliharaan dan perbaikan, pembelian suku cadang, gaji dan tunjangan, pembayaran sewa, dan pembelian bahan bakar serta pemberian imbalan kerja naik sebesar 9,17\%. Beban bandara ialah beban yang dikeluarkan untuk pelayanan pesawat dan penerbangan, grandhouling, pemberian gaji, pembayaran sewa, dan penyusutan naik $14,55 \%$.

Beban tiket, penjualan dan promosi diperoleh dari total pemberian komisi, reservasi, gaji, iuran keanggotaan, promosi, sewa dan pemberian imbalan naik sebesar $4,36 \%$. Pelayanan penumpang naik $4,43 \%$ yang diperoleh atas jumlah pengeluaran pela- yanan penumpang, pemberian gaji, pemakaian persediaan umum, biaya melakukan pelatihan dan jasa profesional. Beban administrasi dan umum naik sebesar $17,20 \%$, dan ada beban operasional yang dikeluarkan oleh pihak perusahaan seperti beban operasional hotel yang mengalami penurunan 7,29\%, operasional transportasi naik $17,81 \%$ dan operasional jaringan naik sebesar $1,04 \%$. Jadi, seluruh jumlah beban usaha yang dikeluarkan perusahaan naik sebesar $11,64 \%$.

Selain itu, ada beban usaha lainnya yang juga mengalami kenaikan maupun penurunan seperti kerugian (keuntungan) selisih kurs mengalami penurunan sebesar $177,08 \%$. Akun Lain-lain disini meliputi keuntungan jual dan sewa balik, biaya pemulihan aset, klaim asuransi, keuntungan revaluasi properti investasi, pendapatan deviden, premi instrumen derivatif, keuntungan (kerugian) penjualan aset tetap dan aset tidak produktif, serta dana perawatan pesawat yang tidak dapat ditagihkan turun $60,63 \%$. Sehingga, secara keseluruhan beban usaha lainnya mengalami penurunan $150,57 \%$.

Besarnya biaya yang tidak sebanding dengan pendapatan perusahaan menjadikan perusahaan mengalami kerugian. Rugi usaha yang dialami perusahaan sebesar $176,87 \%$. Bagian laba (rugi) bersih mengalami penurunan sebesar $189,52 \%$ yang pendapatan keuangannnya juga turun $13,71 \%$. Beban keuangan yang dikeluarkan meliputi bunga atas utang obligasi, utang bank, pinjaman jangka panjang, dan sewa pembiayaan mengalami kenaikan sebesar $0,12 \%$. Sehingga mampu menimbulkan laba (rugi) sebelum pajak namun sayangnya laba (rugi) sebelum pajak turun hingga 989,12\%. Beban pajak naik $555,23 \%$ meliputi pajak kini yang naik sebesar $5,14 \%$ dan pajak tangguhan meningkat sebesar $274,48 \%$. kemudian laba (rugi) bersih tahun berjalan mengalami penurunan hingga $2.378,62 \%$. 
Tabel 8. Analisis Komparatif Tahun Ke Tahun Menggunakan Laporan Laba Rugi Dan Penghasilan Komprehensif Lain Konsolidasian

\begin{tabular}{|c|c|c|c|c|}
\hline \multicolumn{5}{|c|}{$\begin{array}{l}\text { PT GARUDA INDONESIA (PERSERO) TBK dan Entitas Anak } \\
\text { Laporan Laba Rugi dan Penghasilan Komprehensif Lain Konsolidasian }\end{array}$} \\
\hline \multirow{2}{*}{ Keterangan } & 2017 & 2016 & JUMLAH & Persentase \\
\hline & USD & USD & USD & $\%$ \\
\hline PENDAPATAN USAHA & 4.177 .325 .781 & 3.863 .921 .565 & 313.404 .216 & $8,11 \%$ \\
\hline \multicolumn{5}{|l|}{ BEBAN USAHA } \\
\hline Operasional penerbangan & 2.478 .025 .975 & 2.187.316.263 & 290.709 .712 & $13,29 \%$ \\
\hline Pemeliharaan dan perbaikan & 429.361 .211 & 393.308 .458 & 36.052 .753 & $9,17 \%$ \\
\hline Bandara & 382.651 .073 & 334.047 .207 & 48.603 .866 & $14,55 \%$ \\
\hline Tiket, penjualan dan promosi & 323.723 .174 & 310.187 .732 & 13.535 .442 & $4,36 \%$ \\
\hline Pelayanan penumpang & 298.973 .443 & 286.289 .766 & 12.683 .677 & $4,43 \%$ \\
\hline Administrasi dan umum & 265.808 .770 & 226.797 .925 & 39.010 .845 & $17,20 \%$ \\
\hline Operasional hotel & 26.125 .254 & 28.180 .038 & -2.054 .784 & $-7,29 \%$ \\
\hline Operasional transportasi & 21.028 .192 & 17.848 .699 & 3.179 .493 & $17,81 \%$ \\
\hline Operasional jaringan & 12.076 .240 & 11.951 .555 & 124.685 & $1,04 \%$ \\
\hline Jumlah beban usaha & 4.237 .773 .332 & 3.795 .927 .643 & 441.845 .689 & $11,64 \%$ \\
\hline \multicolumn{5}{|l|}{ BEBAN USAHA LAINNYA } \\
\hline Beban pengampunan pajak & 50.307 .992 & - & 50.307 .992 & 0 \\
\hline Kerugian (keuntungan) selisih kurs & $(14.777 .069)$ & 19.170 .712 & -33.947 .781 & $-177,08 \%$ \\
\hline Lain-Lain & 19.797.296 & 50.280 .729 & -30.483 .433 & $-60,63 \%$ \\
\hline Bersih & 15.733 .627 & $(31.110 .017)$ & 46.843 .644 & $-150,57 \%$ \\
\hline LABA (RUGI) USAHA & $(76.181 .178)$ & 99.103 .939 & -175.285 .117 & $-176,87 \%$ \\
\hline Bagian laba (rugi) bersih asosiasi & 192.617 & $(215.172)$ & 407.789 & $-189,52 \%$ \\
\hline Pendapatan keuangan & 6.196 .164 & 7.180 .597 & -984.433 & $-13,71 \%$ \\
\hline Beban keuangan & 88.388 .240 & 88.278 .664 & 109.576 & $0,12 \%$ \\
\hline LABA (RUGI) SEBELUM PAJAK & $(158.180 .637)$ & 17.790 .700 & -175.971 .337 & $-989,12 \%$ \\
\hline Pajak Kini & 18.883 .554 & 17.960 .427 & 923.127 & $5,14 \%$ \\
\hline Pajak tangguhan & 36.325 .487 & 9.700 .306 & 46.025 .793 & $274,48 \%$ \\
\hline BEBAN PAJAK & 55.209 .041 & 8.425 .842 & 46.783 .199 & $555,23 \%$ \\
\hline $\begin{array}{l}\text { LABA (RUGI) BERSIH TAHUN } \\
\text { BERJALAN }\end{array}$ & $(213.389 .678)$ & 9.364 .858 & -222.754 .536 & $-2378,62 \%$ \\
\hline
\end{tabular}

Sumber: Data Diolah (2018).

\section{KESIMPULAN DAN SARAN}

Berdasarkan pembahasan yang telah diuraikan, maka dapat ditarik kesimpulan sebagai berikut yaitu Pertama, Beban pajak yang ditanggung oleh perusahaan ketika tidak melakukan revaluasi aset tetap sebesar USD 8.425.842 dan setelah melakukan revaluasi aset tetap beban pajak yang harus di tanggung perusahaan sebesar USD 55.209.041. Jadi, tindakan revaluasi aset tetap yang telah diterapkan perusahaan belum mampu membantu dalam upaya penghematan pajak penghasilan dikarenakan tanah tidak memberikan kontribusi yang cukup dalam kegiatan tersebut.

Kedua, Perusahaan dalam mencapai struktur modal yang sehat maka perusahaan harus mempertahankan rasio modal yang optimal dan peringkat kredit yang kuat. Sela-ma pinjaman yang digunakan oleh perusahaan akan muncul biaya pinjaman dan biaya pinjaman tersebut diperhitungkan dalam menghitung PKP. Pembebasan koreksi fiskal pada biaya pinjaman dilakukan pada saat rasio modal terhadap hutang tidak melampaui batas maksimal yang telah tertuang di Peraturan Menteri Keuangan Nomor 169/PMK.010/2015. Rasio utang terhadap modal perusahaan setelah menerapkan kebijakan revaluasi aset tetap sebesar 1,8:1. Sehingga, biaya pinjaman yang dikeluarkan oleh perusahaanboleh seutuhnya diakui sebagai beban dikarenakan rasio utang terhadap modal tidak melampaui batas.

Ketiga, Perubahan yang dialami oleh perusahaan setelah menerapkan kebijakan revaluasi aset tetap mengalami penurunan/kerugian yang cukup besar. Kerugian tersebut dikarenakan besarnya beban usaha yang dikeluarkan oleh perusahaan. Namun, pendapatan usaha yang diterima oleh perusahaan mengalami peningkatan sebesar $8,11 \%$. 
Adapun saran penelitian ini lebih ditujukan kepada perusahaan bahwa sebaiknya perusahaan tidak melakukan revaluasi aset pada tanah karena tingginya nilai buku tanah meskipun pada saat revaluasi aset tanah mengalami penurunan dan sifat aset yang tidak dapat disusutkan sehingga membebani dalam hal pengenaan pajak final atas surplus revaluasi. Pihak perusahaan sebaiknya juga mempertimbangkan kembali perencanaan pajak dengan cara lain bukan hanya revaluasi aset.

\section{DAFTAR PUSTAKA}

Atikasari, T. T., \& Handayani, N. (2017). Dampak Revaluasi Aset Tetap Terhadap Pajak Penghasilan. Jurnal Ilmu dan Riset Akuntansi, 6(8).

Garuda Indonesia The Airline of Indonesia. Tentang Garuda Indonesia: Profil Perusahaan. Jakarta. https://www.garuda-indonesia.com/id/, (diakses tanggal 11 Mei 2018)

Ikatan Akuntan Indonesia. 2018. PSAK 16 Aset Tetap. Jakarta: IAI. http://iaiglobal.or.id/, (diakses tanggal 11 Mei 2018)

Peraturan Menteri Keuangan Nomor 79/PMK.03 /2008 Tanggal 23 Mei 2008 Tentang Penilaian Kembali Aset Tetap Perusahaan untuk Tujuan Perpajakan.

Peraturan Menteri Keuangan Nomor. 169/PMK.010 /2015 tentang penentuan besarnya perbandingan antara Hutang dan Modal perusahaan untuk keperluan perhitungan Pajak Penghasilan

Pohan, Chairil Anwar. (2013). Manajemen Perpajakan: Strategi Perencanaan Pajak dan Bisnis. Jakarta: PT Gramedia Pustaka Umum

Ramadhan, Hudan Akbar. (2013). Analisis Revaluasi Aset Tetap Terhadap Penghematan Beban Pajak Penghasilan Pada PT. Inka Madiun. Jurnal Akuntansi Unesa, 1(3).

Subramanyam, K. R., Wild, John J. (2012). Analisis Laporan Keuangan. Jakarta: Salemba Empat

Surat Keputusan Menteri Keuangan Nomor 233/PMK.03/2015 tentang perubahan atas Peraturan Menteri Keuangan Nomor. 191/PMK.03/2015 penilaian kembali aset tetap perusahaan untuk tujuan perpajakan bagi permohonan yang diajukan pada tahun 2015 dan tahun 2016

Undang-Undang Republik Indonesia Nomor 36 Tahun 2008 Tentang Perubahan Keempat Atas Undang-Undang Nomor 7 Tahun 1983 Tentang Pajak Penghasilan

Warren, dkk. (2016). Accounting $27^{\text {th }}$ Edition. USA: Cengage Learning 